\title{
Studies on tapeworms of the common Indian kite,
}

\author{
Milvus migrans (Boddaert) \\ by Santosh Kumari SAXENA \\ Department of Zoology, \\ University of Lucknow, Lucknow, India.
}

\begin{abstract}
Résumé
Un certain nombre de Cestodes ont été récoltés chez le vautour commun des Indes. Milvus migrans (Boddaert). Ils ont été rapportés à 2 espèces de Cestodes seulement. L'une apparaît comme une espèce non décrite de Parvitaenia, Burt 1940, viz. $P$. buckleyi $\mathrm{n}$. sp. - Cette espèce est surtout caractérisée par ses crochets avec leurs accessoires; l'ovaire qui est dendritique et la poche du cirre qui dépasse la partie médiane du proglottis.

L'autre espèce présente certaines ressemblances avec Paradilepsis hierticos (Johri 1934), Matevosyan 1959 d'une part, et d'autre part avec $P$. maleki, Khalil 1961. Une étude du type de $P$. maleki, obligeamment prêtée par l'Ecole de Médecine Tropicale et d'Hygiène de Londres, a pu convaincre l'auteur de sa non identité avec l'espèce de Paradilepsis du rapace indien. Aussi, cette espèce a-t-elle été rapportée à $P$. hierticos, plus particulièrement parce que l'hôte et la localité sont les mêmes. Comme la description originale de cette espèce est brève et peu favorable à une détermination spécifique, une nouvelle description détaillée et critique de l'espèce est donnée dans ce travail.
\end{abstract}

\section{Summary}

Tapeworms of the common Indian Kite, Milvus migrans (Boddaert), have been studied. Only two tapeworms have been found to parasitize this bird. One of them, on study, turned out to be an undescribed species of Parvitaenia Burt, 1940, viz., $P$. buckleyi sp. nov. This species is chiefly characterized by its hooks having appendages, ovary being dendritic, and cirrus sac extending upto the middle of proglottis. The other tapeworm 
bears some resemblance, on one hand, to Paradilepis hierticos (Johri, 1934), Matevosyan, 1959, and, on the other hand, to P. maleki Khalil, 1961. A study of the type of P. maleki, obtained from London School of Hygiene and Tropical Medicine convinced the writer of her form being quite distinct. Hence, this form has been identified as $P$. hierticos, more particularly because the host and the locality are the same. As the original account of this species was brief and inadequate for specific differentiation, a detailed critical account of the species has also been presented in this paper.

The writer, during the course of her investigation on tapeworms of the common pariah kite, Milvus migrans (Boddaert), collected good many specimens of two cestodes from ten birds out of twenty so far examined. One of the cestodes belonged to the genus Parvitaenia Burt, 1940, while the other to Paradilepis Hsü, 1935. They were often found occurring concomitantly. On a thorough study, the specimens of Parvitaenia (about fifty) turned out to be a new species, while those of Paradilepis (over hundred) were found to resemble, on one hand Paradilepis hierticos (Johri, 1934) and, on the other hand, $P$. maleki Khalil, 1961. A study of the type of $P$. maleki convinced the writer of her form being distinct from it. The account of $P$. hierticos, described from kite in India, is too brief and inadequate for specific identification, but from the available data the resemblance between the two is so close that the writer feels her form to be the same - particularly in view of the fact that both are from the same host and locality. A critical redescription of this species based on the writer's material is included in this paper, besides the account of the new form.

A study of literature shows that uptil now only three species of tapeworms, viz., Paradilepis hierticos (Johri, 1934), Raillietina rangoonica (Subramanian, 1928) and Paricterotaenia milvi Singh, 1952, have been described in India from kites by workers (Johri, 1934; Singh, 1952) and the occurrence of one, viz., Paradilepis multihamata (Meggitt, 1927) has also been recorded in this bird (Johri, 1934). So far no specimens of $P$. multihamata, $R$. rangoonica and $P$. milvi have been obtained.

Several species of tapeworms are known from outside India as parasites of $M$. migrans as well as of other species of Milvus (M. milvus, $M$. korschum), but none of them have been so far found in India parasiziting the common kite.

\section{Parvitaenia buckleyi* sp. nov.}

Body small, measuring 5 to $8 \mathrm{~mm}$. in maximum length and 0.268 to $0.460 \mathrm{~mm}$. in maximum width in the region of gravid proglottides. Neck region practically absent. Proglottization starts almost immediately behind the scolex. Strobila consists of 35 to 60 proglottides.

* Named in honour of Professor J. J. C. Buckley. 
Scolex globular or subglobular (fig. 1), measuring 0.140 to $0.175 \mathrm{~mm}$. in length and 0.150 to $0.227 \mathrm{~mm}$. in width in the region of suckers: the latter are highly muscular and unarmed, measuring 0.084 to $0.098 \mathrm{~mm}$. in diameter. Rostellum welldeveloped and armed. In most of the specimens, it is partly everted and measures as such about $0.105 \mathrm{~mm}$. in length and 0.052 to $0.056 \mathrm{~mm}$. in width. Rostellar hooks arranged in two alternate rows, each row comprising ten hooks: hooks of the anterior row are larger than those of the posterior row. Handle of hooks of either row is smaller than the blade. Both handle and guard of hooks are provided with appendages (fig. 2) - this constitutes an important criterion of the present species. Handle
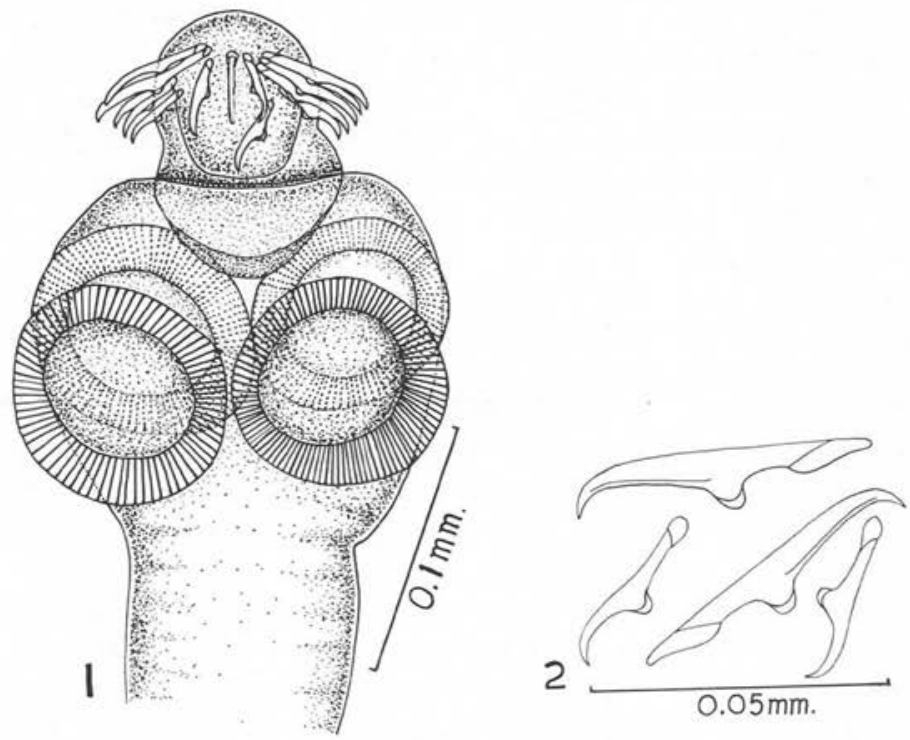

FIG. 1. - Scolex of Parvitaenia buckleyi sp. nov.

Fig. 2. - Anterior $(a)$ and posterior $(b)$ rows of rostellar hooks of Parvitaenia buckleyi sp. nov.

(including the appendage) and blade of hooks of the anterior row measure in length 0.0227 to $0.0262 \mathrm{~mm}$. and 0.0262 to $0.0280 \mathrm{~mm}$. respectively, while those of the posterior row 0.0157 to $0.0175 \mathrm{~mm}$. and 0.0140 to $0.0157 \mathrm{~mm}$. respectively. Total length of rostellar hooks of anterior and posterior rows being 0.0489 to $0.0542 \mathrm{~mm}$. and 0.0297 to $0.0332 \mathrm{~mm}$. respectively.

Proglottides are broader than long, roughly triangular, craspedote and hyperapolytic. Immature proglottides measure 0.104 to $0.124 \mathrm{~mm}$. in length and 0.140 to $0.212 \mathrm{~mm}$. in breadth. Mature proglottides (figs. 3 and 4) measure 0.120 to $0.200 \mathrm{~mm}$. in length and 0.180 to $0.368 \mathrm{~mm}$. in breadth at the middle level; while the corresponding measurements of the gravid proglottides are 0.196 to $0.380 \mathrm{~mm}$. and 0.268 to $0.460 \mathrm{~mm}$. 
Ventral as well as dorsal longitudinal excretory canals are visible on each side in mature proglottides. Dorsal excretory canal thinner than the ventral one and runs in a zigzag course: the former measures $0.003 \mathrm{~mm}$., while the latter is $0.007 \mathrm{~mm}$. in width. Transverse excretory canal, too, thinner than the ventral longitudinal excretory canal.

Testes develop earlier than the female genital organs. They vary from seven to twelve in number and measure 0.016 to $0.056 \mathrm{~mm}$. in diameter. Distribution of testes quite characteristic. Most of them are located posterior and lateral to the ovary; only one, or sometimes two, aporal testis is pre-ovarian ; occasionally one poral testis, too, is found to be pre-ovarian. Vas deferens highly coiled (fig. 4) and located anterior to the female genital complex. Cirrus sac well-developed, elongated, obliquely placed, and runs porally between the excretory canals to open into the genital atrium, and aporally upto the middle of proglottis. It encloses an ejaculatory duct and a long muscular cirrus beset with fine spines, and measures 0.080 to $0.140 \mathrm{~mm}$. $\times 0.016$ to $0.028 \mathrm{~mm}$. Genital pores irregularly alternate and marginally located, usually in the anterior third of mature proglottis, but may be slightly more posterior. Cirrus sac persists in gravid proglottis.

Ovary bilobed in early stages of development, but large and dendritic in fully mature proglottis occupying practically the entire intervascular field, the branches extending right upto the longitudinal excretory canals of either side. It measures transversely 0.072 to $0.132 \mathrm{~mm}$, in mature proglottis. Vitellarium compact, post-ovarian, and measures 0.024 to $0.044 \mathrm{~mm}$. $\times 0.032$ to $0.064 \mathrm{~mm}$. Mehlis gland distinct. Vagina emerging from the oötype complex runs obliquely forward and outwards lying behind the male genital duct. It passes between the excretory canals of the poral side and opens into the genital atrium posterior to the cirrus sac. Proximally it is dilated forming a large prominent fusiform receptaculum seminis which measures 0.040 to $0.060 \mathrm{~mm}$. $\times 0.024$ to $0.040 \mathrm{~mm}$. Receptaculum seminis contains enormous amount of sperms in proglottides wherein testes show signs of waning. It is continued into a short fertilization canal leading into the oötype masked by the Mehlis gland. In gravid proglottis, uterus is bilobed (fig. 5) and contains eggs with developing embryos. Hexacanths could not be detected in eggs contained in the uteri of gravid proglottides intact, possibly further development of embryos occurs after the detachment of the latter: condition appears to be hyperapolytic as defined by Pintner (vide Wardle and McLeod, 1952).

\section{Discussion.}

Until quite recently, only five species were described under the genus Parvitaenia Burt, 1940, viz., P. ardeolae Burt, 1940 ; P. cochlearii Coil, 1955 ; P. gorsakii Yamaguti, 1956; P. magna Baer, 1959, and P. purpurea Johri, 1959. In 1959, Yamaguti transferred two species to Parvitaenia, viz., Anomotaenia macropterygis Hübscher, 1937, and his own previously described species Anomotaenia nycticoracis Yamaguti, 1935. The writer agrees with Yamaguti (1959) on this point as these species conform to the characters of this genus Parvitaenia. Subsequently, in 1960, Baer and Bona in their preliminary studies on dilepid cestodes added nine more species to this genus, 


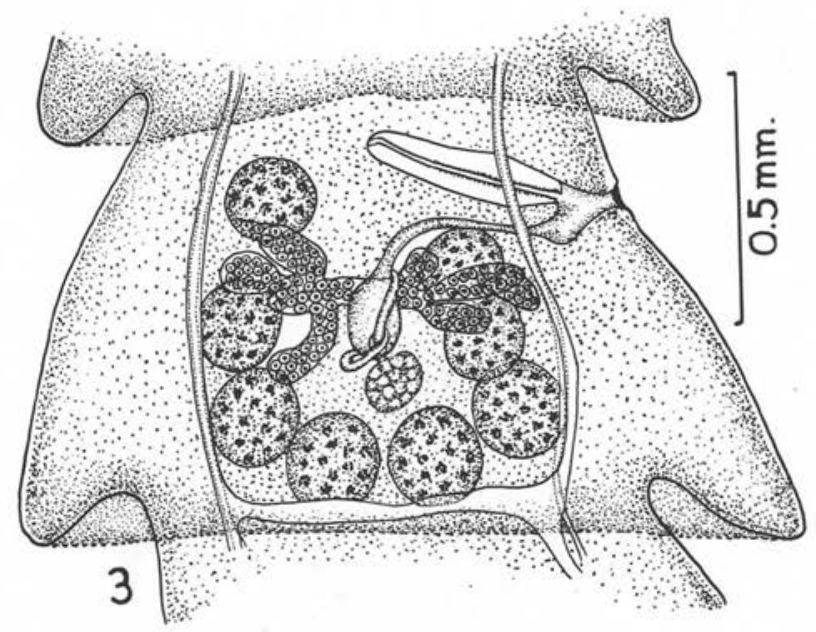

FIG. 3. - Mature proglottis of Parvitaenia buckleyi sp. nov. (vas deferens omitted)

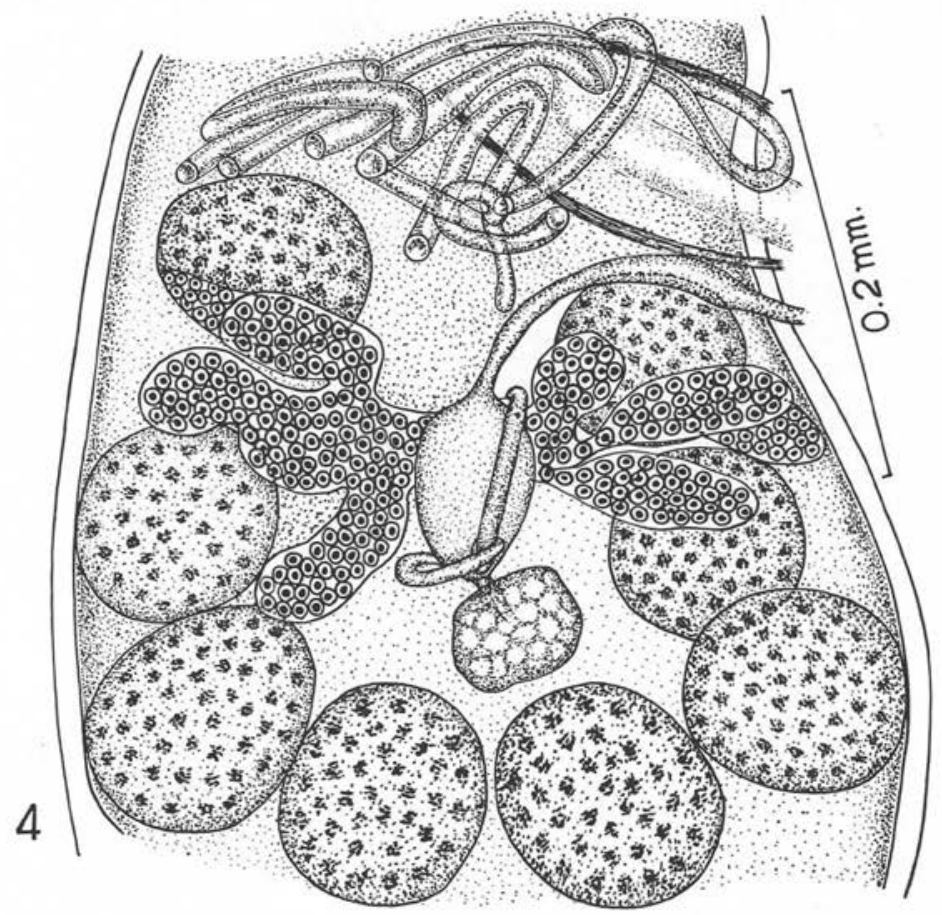

FIG. 4. - Enlarged diagram of the same mature proglottis showing vas deferens 
viz., P. macropeos (Wedl, 1855); P. ardeae (Johnston, 1911) ; P. glandularis (Führmann, 1905) ; P. aurita (Rudolphi, 1918) ; P. macrophallica Baer and Bona, 1960 ; P. microphallica Baer and Bona, 1960 ; P. ambigua Baer and Bona, 1960 ; P. clavipera

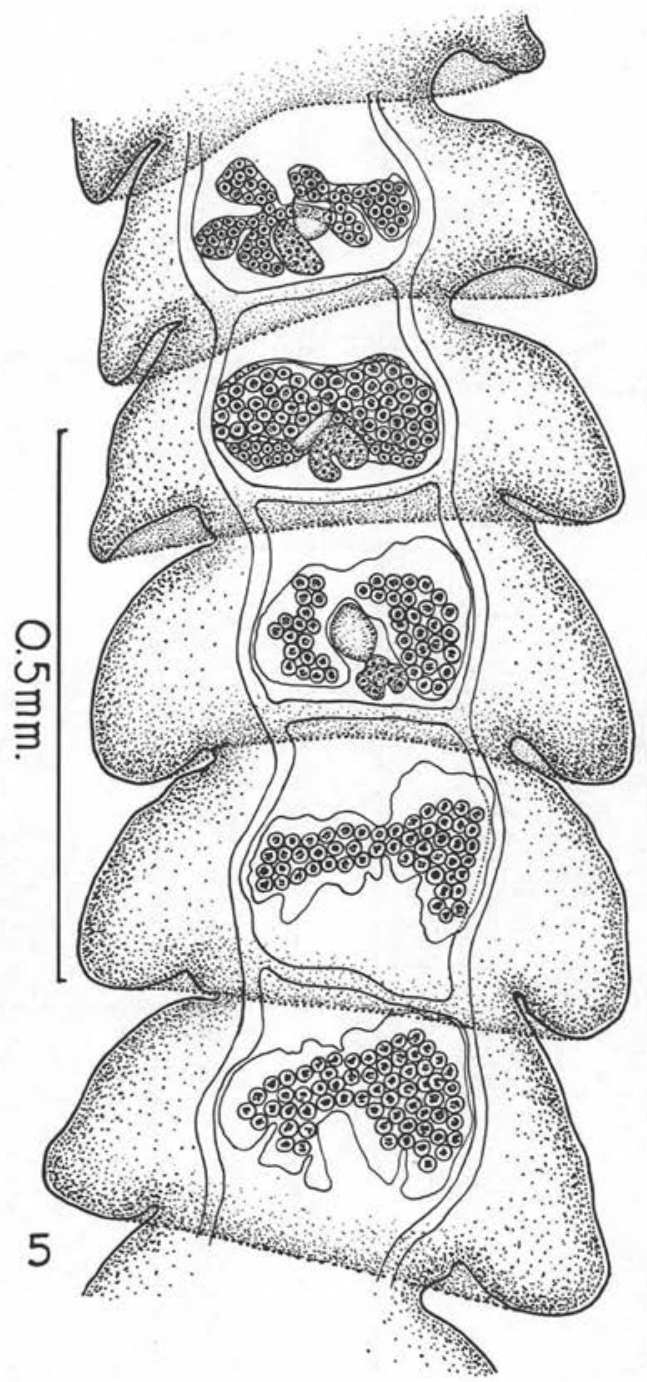

Fig. 5. - Gravid proglottides of Parvitaenia buckleyi sp. nov.

Baer and Bona, 1960, and P. pseudocyclorchida Baer and Bona, 1960. Recently the writer (Saxena, 1968) also transferred Dilepis campylancristrota (Wedl, 1855), D. capellae Yamaguti, 1935, and D. ardeolae Singh, 1952, to the genus Parvitaenia. 
Of all the aforesaid species, the present form closely resembles $P$. adeolae Burt, 1940 ; P. cochlearii Coil, 1955 ; P. gorsakii Yamaguti, 1956 ; P. nycticoracis (Yamaguti, 1935), and $P$. purpurea Johri, 1959. From these, it can be distinguished as follows: in the present form, both handle and guard of hooks are provided with appendages, but not in other species. This is an important distinctive feature of the present species. Ovary dendritic in the writer's form, but bilobed or multilobed in others. Cirrus sac presents another distinctive feature. In the writer's form it extends porally beyond the ventral longitudinal excretory canal, but not in $P$. ardeolae. Further, the cirrus sac in the present form, in spite of the larger size of the latter, does not extend upto the aporal excretory canal but it does in $P$. cochlearii. In $P$. gorsakii and $P$. nycticoracis, the cirrus sac extends beyond the middle of proglottis, but not in the writer's form. The cirrus sac is an elongated structure in the present form, but a flask-shape structure with a globular proximal part and a narrow distal part in $P$. purpurea.

The present form differs from $P$. cochlearii and $P$. gorsakii in the absence of prostatic cells around the vas deferens: it also differs from the former in the absence of a vaginal sphincter, and from the latter in the position of the genital pores. In the writer's form, the genital pores are irregularly alternate but in $P$. gorsakii they are unilateral. Annular muscle band at the opening of the cirrus sac into the genital atrium, which characterizes $P$. purpurea, is absent in the present form.

The writer's form further differs from all these species except $P$. nycticoracis in the number and arrangement of testes; in the present form, testes are 7 to 12 in number ; while in others, they range from 5 to 9 . Moreover, in the present form, the testes are arranged in a rosette around the ovarian complex but not in others. Lastly, the writer's form differs from all but $P$. nycticoracis in having a much larger body. Apart from the characters of rostellar hooks and ovary, and arrangement of testes, the present form can be distinguished from $P$. nycticoracis by the following features: in body size, it is smaller than $P$. nycticoracis, but, on the contrary, in the size of the scolex, suckers, rostellum and rostellar hooks, it is larger. It also differs from $P$. nycticoracis in the smaller size of its cirrus sac and in the absence of hair-like vaginal spines which characterize $P$. nycticoracis.

It would not be out of place for the writer to mention here that the present form bears some resemblance to Paricterotaenia milvi described by Singh (1952) from an Indian kite. In order to make a comparision, an attempt was made to obtain the type specimen of this species from the Director, Zoological Survey of India, Calcutta, but sadly the slide was not traceable in the collection of the Survey. One fundamental difference is found in the number of rows of rostellar hooks of these two forms: the present form has two rows of rostellar hooks, while Singh's form has only one Further, handle and guard of rostellar hooks in the writer's form are provided with appendages, but these structures are not described in $P$. milvi: the figure of the rostellar hook of $P$. milvi (fig. 17, Singh, 1952) apparently indicates the handle to have one. Besides these differences, the writer's form has spinose cirrus, but Singh's form has aspinose cirrus. 
Paradilepis bierticos (Johri, 1934) Matevosyan. 1959.

In all about two hundred and seventy specimens of this tapeworm were collected from ten birds. Usually over thirty, but sometimes about a dozen specimens were collected from individual birds.

Body measures $7 \mathrm{~mm}$. in maximum length and includes about ninety proglottides. Strobilization immediately follows the scolex. Strobila, in specimens with gravid proglottides intact, measures 6.3 to $6.8 \mathrm{~mm}$. in length. Anteriorly the lateral margins of strobila lightly serrated, but posteriorly quite smooth in the region of gravid proglottides.

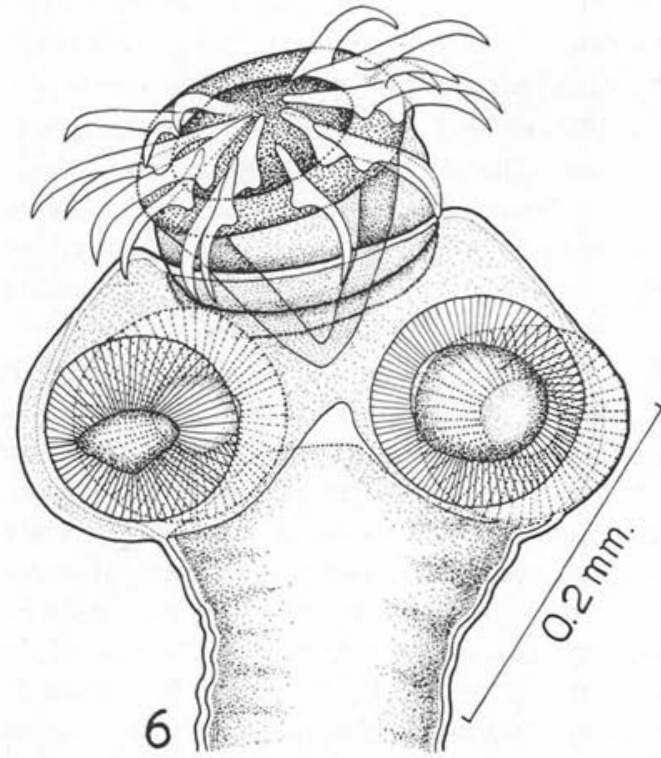

FIg. 6. - Scolex of Paradilepis hierticos (Johri, 1934)
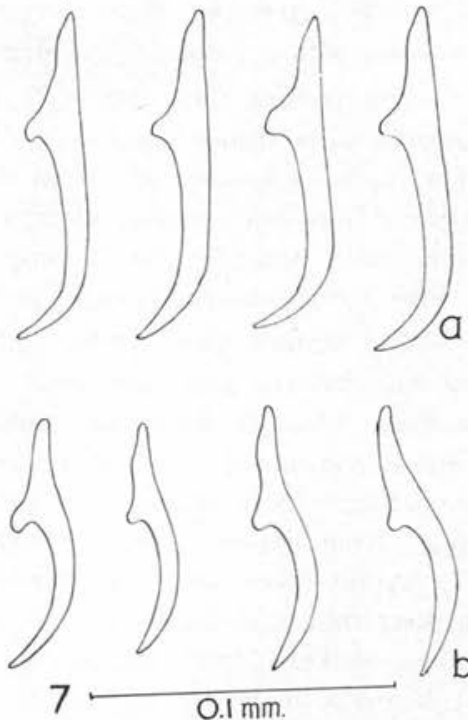

Fic. 7. - Anterior (a) and posterior (b) rows of rostellar hooks of Paradilepis hierticos (Johri, 1934)

Scolex (fig. 6) measures 0.18 to $0.30 \mathrm{~mm}$. in length and 0.24 to $0.39 \mathrm{~mm}$. in width. Suckers well-developed and measure 0.09 to $0.12 \mathrm{~mm}$. in diameter. They are slightly smaller than those of Johri's material. Everted rostellum (fig. 6) measures 0.153 to $0.168 \mathrm{~mm}$. in length and 0.105 to $0.165 \mathrm{~mm}$. in width. It is armed with two alternate rows of hooks, each row includes ten hooks. Johri (1934) in his account stated the rostellar hooks to be 16 to 18 . In none of the specimens in the possession of the writer, hooks have been found more than 20 , a figure which certainly appears to be the full complement. It seems certain that some of the hooks must have been missing from the specimens (number of which has not been mentioned by the author) studied by Johri (1934). Of the two rows of rostellar hooks, the anterior row includes larger, while the posterior one smaller hooks (fig. 7). Blade of rostellar hooks much 
longer than the handle as shown in the figure by Johri (1934). Blade and handle of rostellar hooks of the anterior row measure in length 0.068 to $0.084 \mathrm{~mm}$. and 0.036 to $0.040 \mathrm{~mm}$. respectively, while those of the posterior row 0.048 to $0.060 \mathrm{~mm}$. and 0.028 to $0.036 \mathrm{~mm}$. respectively.

Proglottides acraspedote and apolytic. Immature proglottides are much broader than long, and measure 0.01 to $0.06 \mathrm{~mm}$. in length and 0.12 to $0.24 \mathrm{~mm}$. in breadth. Mature and gravid proglottides are also broader than long (figs. 8 and 11), the former

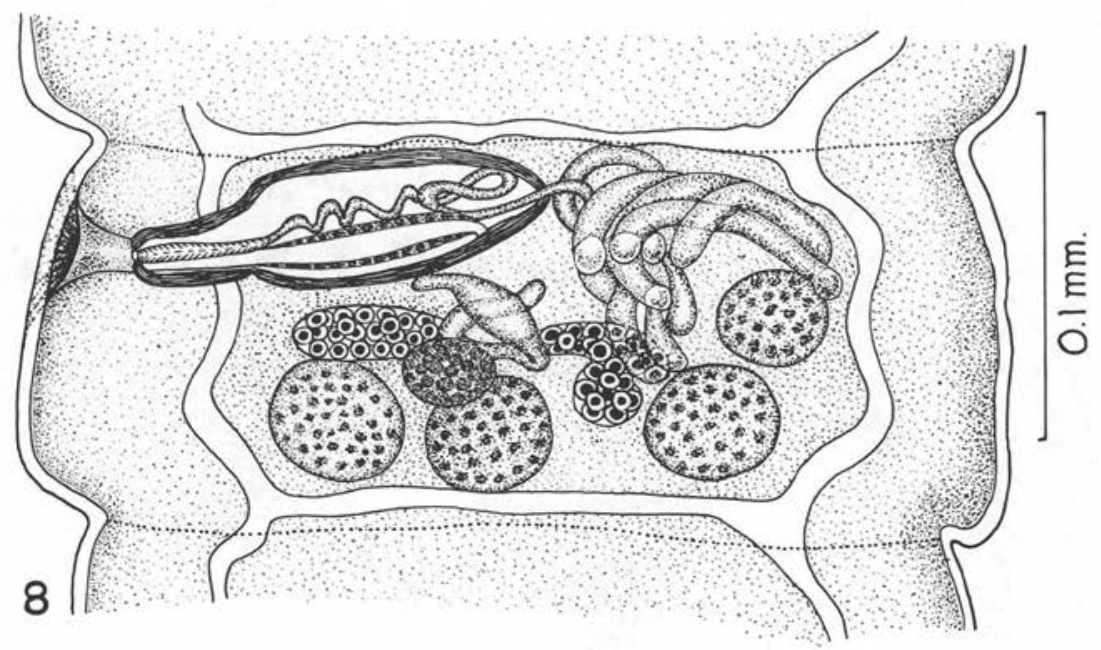

FIG. 8. - Mature proglottis of Paradilepis hierticos (Johri, 1934)

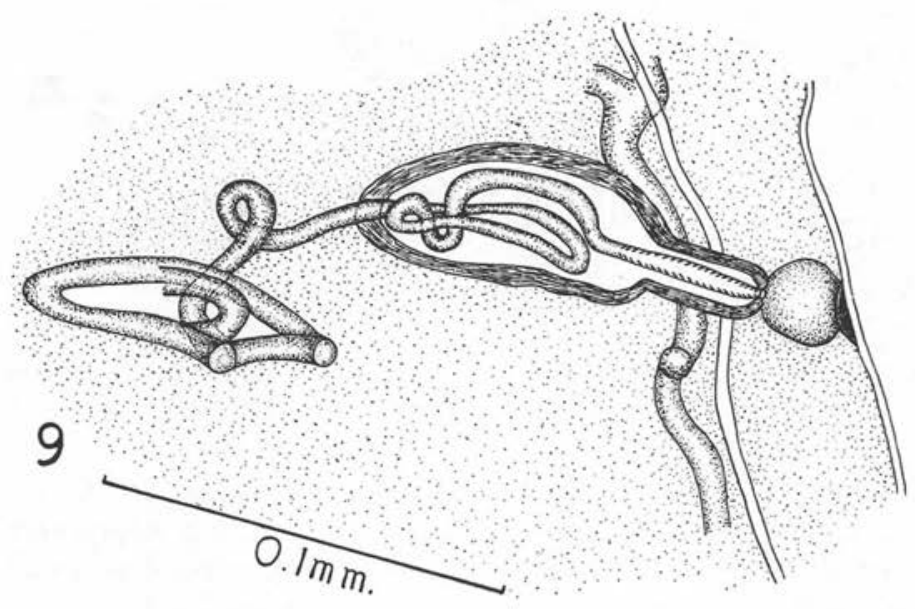

FIg. 9. - Cirrus sac of Paradilepis hierticos (Johri, 1934) enlarged 
measure 0.06 to $0.16 \mathrm{~mm}$. in length and 0.28 to $0.34 \mathrm{~mm}$. in breadth, while the latter 0.12 to $0.20 \mathrm{~mm}$. in length and 0.26 to $0.30 \mathrm{~mm}$. in breadth.

Longitudinal bundles of parenchymal muscles (fig. 10) run in two rows - an outer and an inner. Inner row is interrupted laterally and consists of thicker bundles which usually number 20 to 24 dorsally as well as ventrally. The writer does not find the inner bundles to be feebly developed as stated by Johri (1934). Bundles of the outer row are thinner and more numerous than those of the inner row, and they run in a continuous layer around the latter. Circular muscles are hardly distinguishable and appear to be poorly developed.

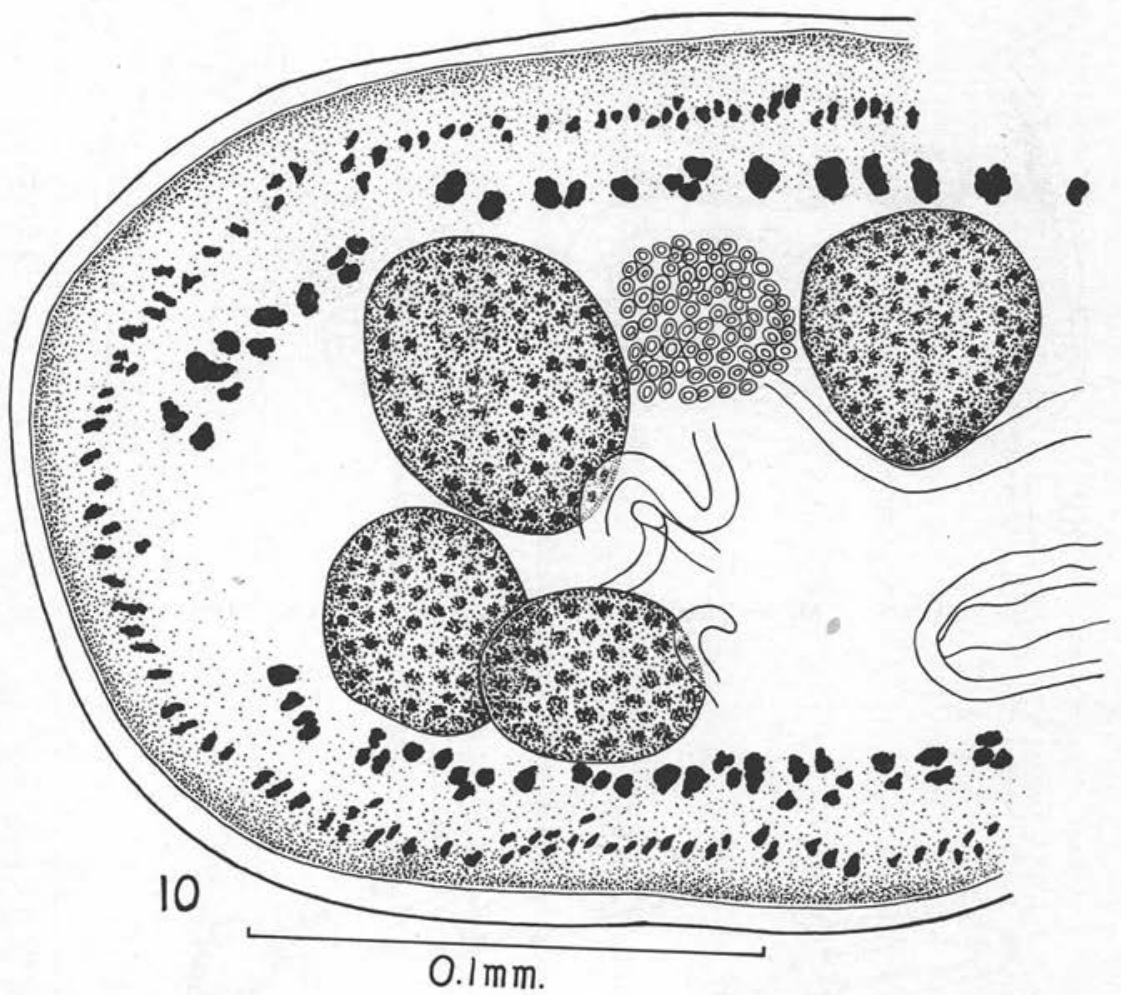

FIG. 10. - T.S. of a mature proglottis of Paradilepis hierticos (Johri, 1934) showing parenchymal musculature, gonads and genital ducts

Ventral as well as dorsal longitudinal excretory canals are visible on each side, the former is much wider than the latter and they measure respectively 0.008 to $0.016 \mathrm{~mm}$. and $0.004 \mathrm{~mm}$. in width. Transverse excretory canal is about the width of the dorsal longitudinal excretory cana', or slightly wider, and measures 0.004 to $0.006 \mathrm{~mm}$. in width. 
Testes globular or subglobular, invariably four in number and located (fig. 8) close to the posterior border of proglottis; two of them are aporal, one poral, and one median. Aporal testes are obliquely tandem, the anterior one being partly or entirely in front of ovary. Johri (1934) stated one testis to be aporal and anterior to the others which are located in a transverse row posterior and lateral to the ovary, but from his figure (fig. 12, Johri, 1934) two testes appear to be aporal, of which one is more anterior, one poral, and one median exactly as in the writer's material. In most of the proglottides testes are more or less of equal size, but in some they are markedly unequal ; they range in size from 0.02 to $0.04 \mathrm{~mm}$. in diameter. Johri's (1934) account lacks in measurements of the testes. Vas deferens densely coiled, extending upto the aporal ventral excretory canai and often abutting against the latter. Eventually it enters into the cirrus sac as a convoluted ejaculatory duct which terminates in an elongated muscular cirrus thickly beset with spines. Vesicula seminalis interna nor externa developed. Johri does not state the nature of cirrus sac. The writer finds the cirrus sac in her specimens to be thick-walled having a characteristic shape. It has a bottle-shape (figs. 8 and 9) with a narrow neck which is usually distinctly marked off from the remaining part by pronounced shoulders, but occasionally the shoulders are ill-defined. It is located, with its neck directed outwards, close to the anterior border of proglottis. It runs dorsal to the excretory canals and opens into a deep infundibular genital atrium; its mesial end extends upto the middle of proglottis. In this respect, too, the present material shows some difference as the cirrus sac in Johri's specimens does not reach the middle of proglottis as is evident from his figure (fig. 12, Johri, 1934). It measures 0.084 to $0.120 \mathrm{~mm}$. in length and 0.028 to $0.036 \mathrm{~mm}$. in maximum breadth. The genital pores unilateral and located in the anterior half of mature proglottis. Johri (1934) states the genital pore as being located in the anterior third of proglottis, but his figure shows that this pore is located in the anterior half as in the writer's specimens. In gravid proglottis, the cirrus sac seems to persist.

Ovary, when fully developed, is a bilobed structure (figs. 8 and 12) with a narrow isthmus; each lobe being transversely elongated. It is located in the median field, often abutting posteriorly against the poral, median, and posterior aporal testes, and measures transversely 0.092 to $0.180 \mathrm{~mm}$., while each lobe measures 0.012 to 0.060 $\mathrm{mm}$. in length and 0.028 to $0.068 \mathrm{~mm}$. in breadth. Vitellarium compact and oval in outline, transversely placed in the median field, immediately behind the ovary and measures 0.036 to $0.040 \mathrm{~mm}$. lengthwise and 0.016 to $0.036 \mathrm{~mm}$. breadthwise. Oötype complex greatly masked by the middle part of ovary and vitellarium. Vagina (figs. 8 and 12) is a wide tubular structure and runs ventral to the cirrus sac but dorsal to the excretory canals. It extends inwards from the genital atrium to about threefourths the length of the cirrus sac wherefrom it turns posteriorly and soon widens to form an exceedingly large fusiform receptaculum seminis (fig. 8 and 12), but thereafter it narrows again to continue as a fine fertilization canal to open into the oötype. In early gravid proglottides, uterus appears as a small biloted structure with simple eggs, but in later stages it contains developing eggs. In fully gravid proglottides (fig. 11), the lobes of uterus are much enlarged and are closely approximated in the median 


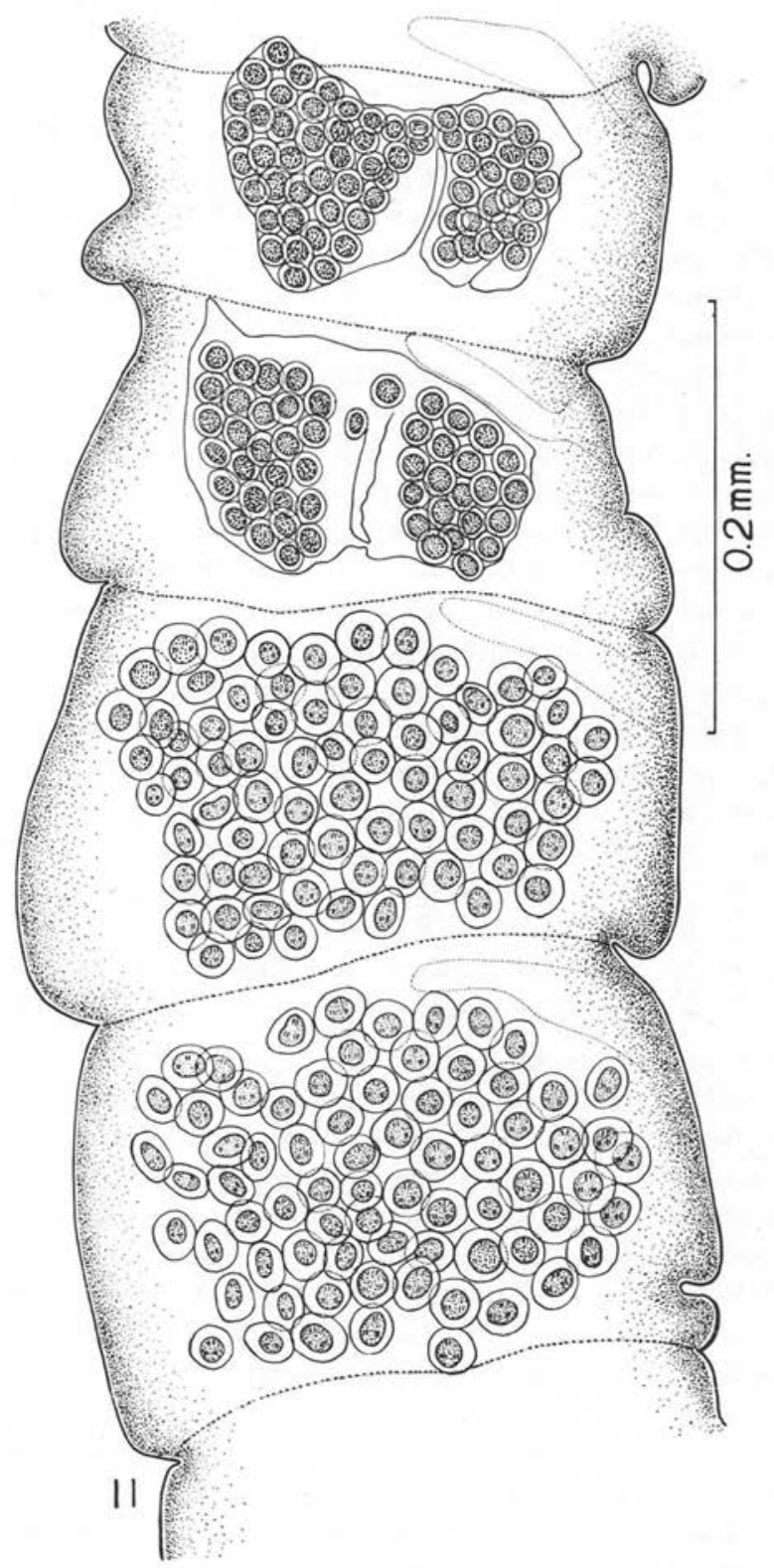

Fig. 11. - Gravid proglottides of Paradilepis hierticos (Johri, 1934) 


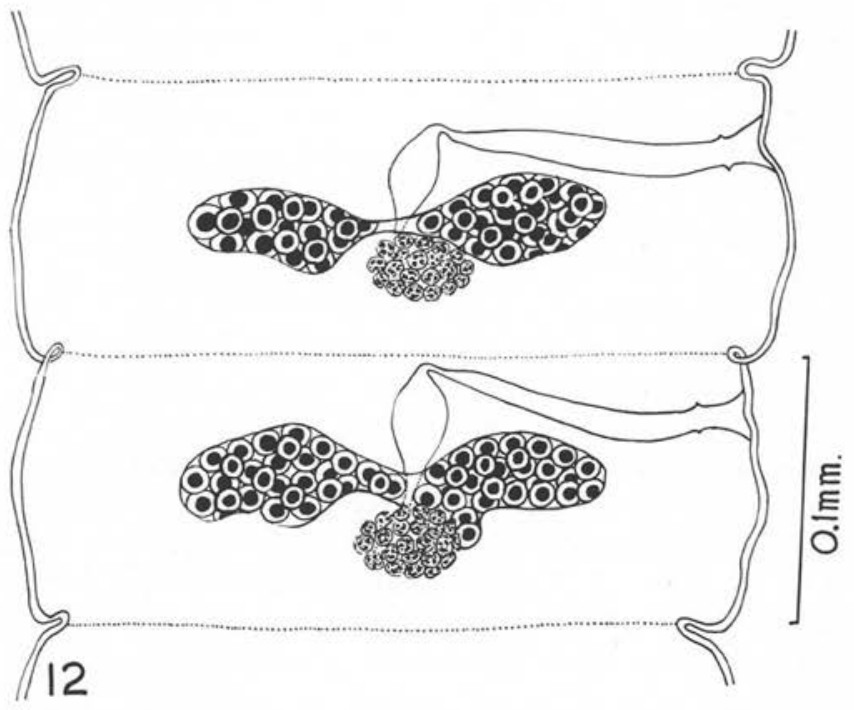

FIg. 12. - Female genital complex of Paradilepis hierticos (Johri, 1934)
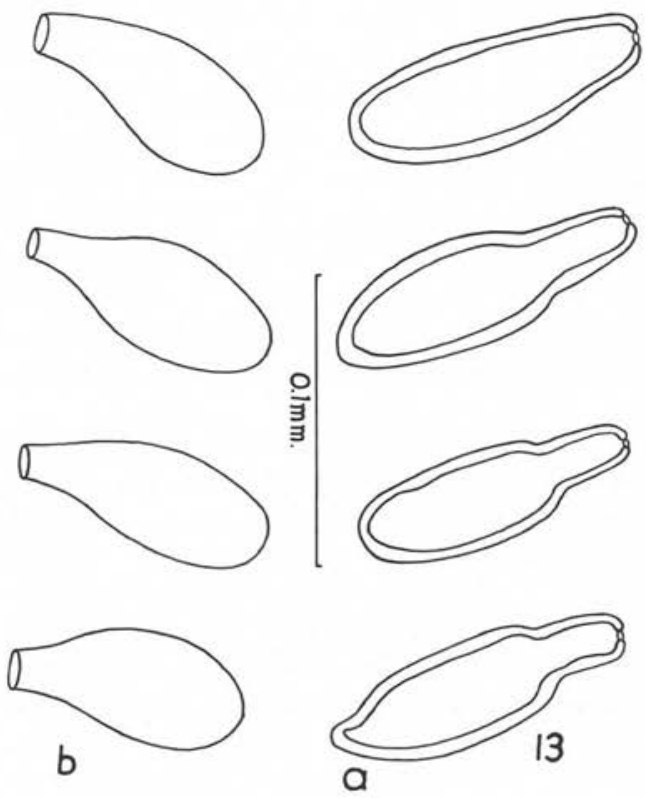

FIG. 13. - Cirrus sacs drawn from (a) $P$. hierticos (Johri, 1934) and from (b) P. maleki Khalil, 1961 
line. The embryonated eggs in mounted specimens measure 0.0175 to $0.0210 \mathrm{~mm}$. in diameter, but when teased out of live gravid proglottides in saline, they measure 0.0350 to $0.0700 \mathrm{~mm}$. in diameter; likewise, the contained hexacanths measure in the former $0.0105 \mathrm{~mm}$. and in the latter 0.0175 to $0.0350 \mathrm{~mm}$. in diameter. Handle and blade of the embryonic hooks measure $0.0070 \mathrm{~mm}$. and $0.0035 \mathrm{~mm}$. in length respectively.

\section{Discussion.}

Paradilepis hierticos (Johri, 1934) closely resembles P. maleki Khalil, 1961, which, to the best knowledge of the writer, is the only species so far described with twenty rostellar hooks and with four testes arranged in the same way as they are in the present form. Indeed, the present material, treated here as Paradilepis hierticos, and $P$. maleki appear alike. Through the courtesy of Professor J. J. C. Buckley, the writer has been able to examine the type of P. maleki Khalil, 1961, from the collection of London School of Hygiene and Tropical Medicine. As Khalil (1961) has not given some measurements, the writer has taken the required measurements from the type. The appended table gives the measurements of $P$. hierticos and $P$. maleki. The writer finds that $P$. hierticos is much larger in body size - as much as three times the size of $P$. maleki. Further, the mature proglottides of the present form are slightly longer but decidedly broader than those of $P$. maleki. Rostellar hooks of both anterior and posterior rows are much larger in the present form than the corresponding hooks of $P$. maleki. The cirrus sac, too, is larger and thick-walled in the present form, but not so in $P$. maleki. In shape, the cirrus sac of the two (fig. 13) differs: the present form has a characteristic bottle-shape cirrus sac, while $P$. maleki has an elongate-oval cirrus sac. In the size of the eggs, the present form also differs: the eggs in the present form measure 0.0175 to $0.0210 \mathrm{~mm}$. in diameter (mounted specimen), while in $P$. maleki they measure 0.0105 to $0.0140 \mathrm{~mm}$. Apart from these differences in the size of different structures, the writer finds that the testes in her form are quite discrete, while they are contiguous in the type of $P$. maleki which certainly appears to be a fairly well-extended specimen. In spite of the large size of the body, rostellar hooks, cirrus sac and eggs, $P$. hierticos has relatively small testes.

ACKNOWLEDGEMENTS. The writer feels pleasure in acknowledging her grateful thanks to Professor P. D. Gupta, Head of the Department of Zoology, for providing laboratory facilities ; to $\mathrm{D}^{r}$ S. C. Baugh for supervising the work, to Professor J. J. C. Buckley, London School of Hygiene and Tropical Medicine, London, for lending the type slide of Paradilepsis maleki Khalil, 1961; to Professor J. G. Baer, Neuchâtel Université, Switzerland, for providing the author with literature; to Mother M. Cyril Mooney, I.B.V.M., Lucknow, for translating some French literature, and lastly to the authorities concerned of the University Grants Commission, Government of India, for awarding a Research Training Scholarship to the writer which has enabled her to take up the work. 


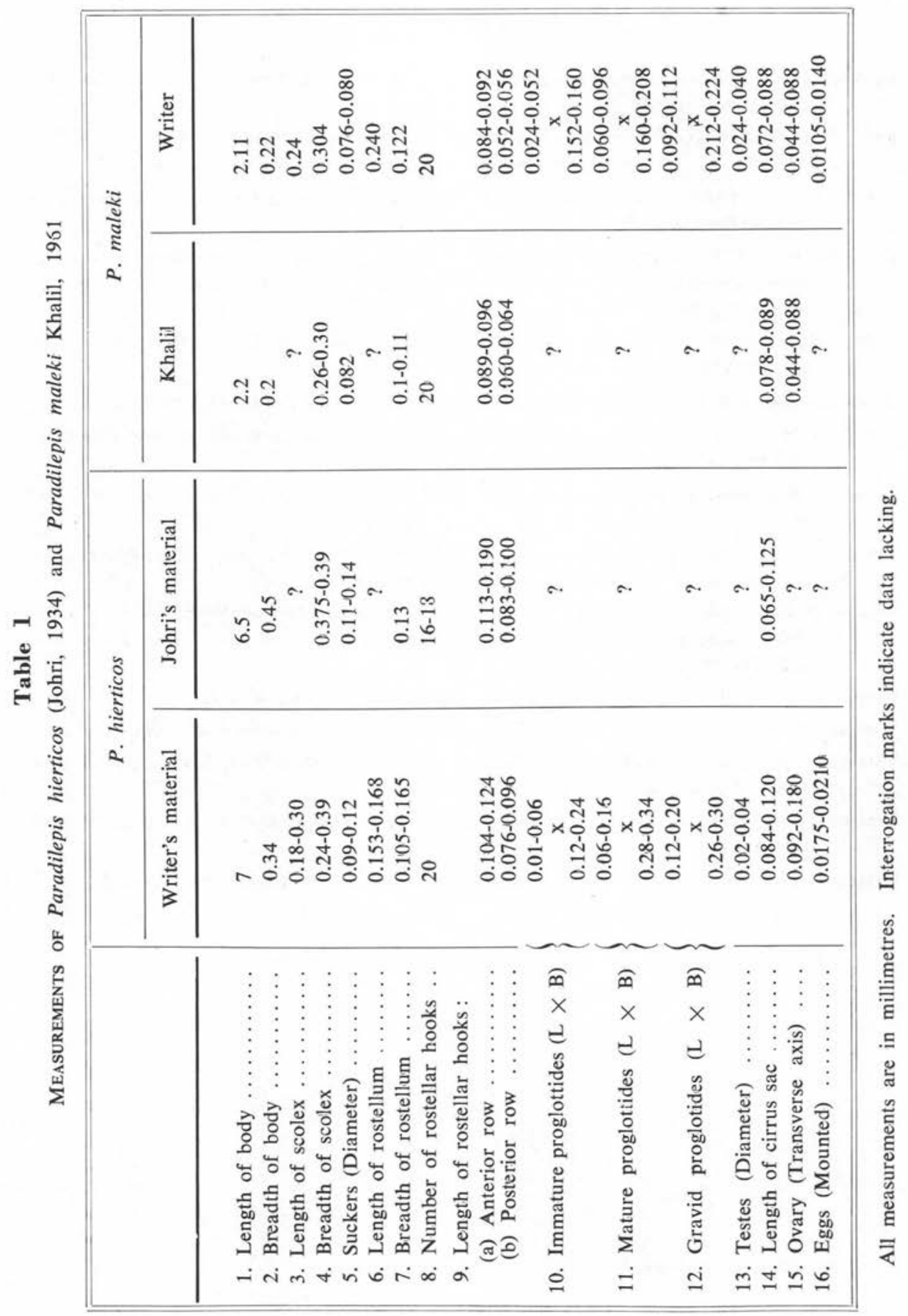




\section{Bibliography}

Baer (J. G.), 1959. - Helminthes Parasites. Explor, Parcs nat. Congo. Belge, Miss. Baer and Gerber (1958), 1, 1-163.

Baer (J. G.) et Bona (F.), 1960. - Révision des cestodes Dilepididae Führm., 1907 des Ardeiformes. Note préliminaire. Boll. 1st. Mus. Zool. Univ. Torino., 6, 1-53.

BURT (D R. R.), 1940. - New species of Cestodes from Charadriiformes, Ardeiformes and Pelecaniformes in Ceylon. Ceylon J. Sci., B, 22, 1-63.

Corl (W. H.), 1955. - Parvitaenia cochlearii sp. nov. (Cestoda: Dilepididae) a new tapeworm parasitic in the boat-billed heron, Cochlearius cochlearius. Proc. Helm. Soc. Wash., 22, 66-68.

* Hsü (H. F.), 1935. - Contributions à l'étude des cestodes de Chine. Rev. suisse Zool., 42, 447-570.

HüвsCher (H.), 1937. - Notes helminthologiques. Rev. Suisse Zool., 42, 459-482.

Johri (G. N.), 1959. - Two new species of Cestodes belonging to the family Dilepididae Führm., 1907. J. Zool. Soc. India, 11, 60-64.

JoHRI (L. N.), 1934. - Report on a collection of cestodes from Lucknow. Rec. Ind. Mus., 36, 153-177.

Khalil (L. F.), 1961. - On a new cestode, Paradilepis maleki sp. nov. (Dilepididae), from a sacred ibis in the Sudan. J. Helm., 35, 255-258.

SAXena (S. K.), 1968. - A restudy of Parvitaenia campylancristrota (Wedl, 1855) n. comb. with a note on the taxonomy of the genus Parvitaenia Burt, 1940. Zool. Anz., 183, 284-291.

SingH (K. S.), 1952. - Cestode parasites of birds. Ind. J. Helm., 4, 1-72.

WARdLE (R. A.) et McLeod (J. A.), 1952. - The zoology of tapeworms, 477-494.

Yamaguti (S.), 1935. - Studies on the Helminth Fauna of Japan. Part. 6. Cestodes of birds. Japan. J. Zool., 6, 183-232.

Yamaguti (S.), 1956. - Parasitic worms mainly from Celebes. Part II. Cestodes of birds. 1-41.

Yamaguti (S.), 1959. - Systema Helminthum. 11. Cestodes of Vertebrates. 227-258.

\footnotetext{
* Not consulted in original.
} 